\title{
The Aryl Hydrocarbon Receptor and the Maintenance of Lung Health
}

\author{
Necola Guerrina ${ }^{1,2}$, Hussein Traboulsi ${ }^{1}$, David H. Eidelman ${ }^{1,3}$ and Carolyn J. Baglole ${ }^{1,2,3,4, *}$ \\ 1 Research Institute of the McGill University Health Centre, Montreal, QC H4A 3J1, Canada; \\ necola.guerrina@mail.mcgill.ca (N.G.); hussein.traboulsi@mail.mcgill.ca (H.T.); \\ david.h.eidelman@mcgill.ca (D.H.E.) \\ 2 Department of Pathology, McGill University, Montreal, QC H3A 2B4, Canada \\ 3 Department of Medicine, McGill University, Montreal, QC H4A 3J1, Canada \\ 4 Department of Pharmacology and Therapeutics, McGill University, Montreal, QC H3G 1Y6, Canada \\ * Correspondence: carolyn.baglole@mcgill.ca; Tel.: +1-(514)-934-1934 (ext. 76109)
}

Received: 1 November 2018; Accepted: 29 November 2018; Published: 5 December 2018

\begin{abstract}
Much of what is known about the Aryl Hydrocarbon Receptor (AhR) centers on its ability to mediate the deleterious effects of the environmental toxicant 2,3,7,8-tetrachlorodibenzo-p-dioxin (TCDD; dioxin). However, the AhR is both ubiquitously-expressed and evolutionarily-conserved, suggesting that it evolved for purposes beyond strictly mediating responses to man-made environmental toxicants. There is growing evidence that the $\mathrm{AhR}$ is required for the maintenance of health, as it is implicated in physiological processes such as xenobiotic metabolism, organ development and immunity. Dysregulation of AhR expression and activity is also associated with a variety of disease states, particularly those at barrier organs such as the skin, gut and lungs. The lungs are particularly vulnerable to inhaled toxicants such as cigarette smoke. However, the role of the AhR in diseases such as chronic obstructive pulmonary disease (COPD) - a respiratory illness caused predominately by cigarette smoking — and lung cancer remains largely unexplored. This review will discuss the growing body of literature that provides evidence that the AhR protects the lungs against the damaging effects of cigarette smoke.
\end{abstract}

Keywords: aryl hydrocarbon receptor; lung; cigarette smoke; chronic obstructive pulmonary disease

\section{Introduction}

The Aryl Hydrocarbon Receptor (AhR) is a ligand-activated transcription factor that is evolutionarily-conserved among multicellular organisms [1]. The expression and distribution of AhR was recently reviewed [2]. Although ubiquitously-expressed, the level of AhR expression is variable. For example, the highest expression of the AhR occurs in first-line defense organs such as the lungs, skin, liver and gut [2]. The AhR belongs to the basic helix loop helix (bHLH)/PER-ARNT-SIM (PAS) family whose members are involved in the sensing of exogenous and endogenous stimuli [3]. The AhR belongs to the bHLH superfamily marked by the presence of a basic domain and a HLH domain. The basic domain enables binding of the AhR to DNA, whereas the HLH domain enables protein dimerization [4]. This superfamily has been further subdivided phylogenetically into six classes (A-F). The AhR belongs to bHLH class $\mathrm{C}$, as it both recognizes and binds ACGTG or GCGTG DNA sequences and contains a PAS domain [4]. The bHLH and PAS domains are located on the amino-terminus of the AhR protein, whereas the transactivation domain is found on the carboxy-terminus and influences the nucleo-cytoplasmic shuttling functions of the amino-terminus [5].

Conventionally, the AhR is activated by a wide variety of agonists of either exogenous or endogenous origin. These ligands are typically hydrophobic in nature and thus enter the cell via simple 
diffusion through the plasma membrane [6]. AhR ligands are also classically small (i.e., estimated to be between 1.2 and $1.4 \mathrm{~nm}$ in length) and planar substances [7], although structurally-diverse ligands that deviate from these properties have been recently identified [8]. Even a complex mixture such as cigarette smoke (CS) is an AhR agonist, inducing significant AhR activation in vitro $[9,10]$ and in vivo [11,12]. CS contains more than 5000 chemicals, including metals (iron, nickel), gases (ozone), biological agents (plant pollen, endotoxins, bacteria), minerals (quartz, asbestos) and organic chemicals such as nicotine, polychlorinated dibenzodioxins [PCDDs] and polycyclic aromatic hydrocarbons [PAH] [13-16]. Many of the individual organic chemicals found in CS are also ligands of the AhR [11,17]. Although the AhR may mediate carcinogenicity induced by individual components of CS, such as 2,3,7,8-tetrachlorodibenzo-p-dioxin (TCDD) [18] and benzo[a]pyrene [19], it simultaneously protects against many of the pathogenic effects of CS in the lung [9-12,20]. This demonstrates that CS is more than simply the sum of its parts and that CS represents an AhR agonist that is structurally and functionally distinct from the individual constituents of CS.

Cigarette smoking is the primary cause of prevalent respiratory pathologies such as chronic obstructive pulmonary disease (COPD) and lung cancer, contributing to approximately $75 \%$ of both COPD [21] and lung cancer [22] cases. The pathogenesis of these diseases involves the deregulation of cellular processes including cell survival, migration and proliferation. These cellular processes are also controlled by the AhR [23-26]. It remains controversial however, as to the extent to which aberrant AhR expression and/or activation contributes to disease. For example, over-expression of the AhR occurs in many types of human cancers, including lung, breast and gastric cancers $[25,27-30]$ and there is recent evidence supporting a pro-oncogenic role for AhR over-expression in lung cancer [31]. Whether the AhR contributes to the pathogenesis of COPD remains unexplored. The focus of this review is to highlight the growing body of literature that demonstrates a role for the AhR in attenuating CS-induced lung injury, with particular emphasis on COPD.

\section{The Aryl Hydrocarbon Receptor (AhR)}

\subsection{AhR Ligands}

\subsubsection{Exogenous AhR Agonists}

The best characterized class of AhR ligands are exogenous environmental toxicants, including PAHs and halogenated aromatic hydrocarbons (HAHs) [7]. Both PAHs and HAHs are produced from the incomplete combustion of organic compounds, which can occur naturally (e.g., forest fires and volcanic eruptions) or from anthropogenic sources (e.g., burning of fossil fuels, pulp and paper manufacturing, air pollution, CS) [8]. Exposure to PAHs and HAHs typically induces the expression of xenobiotic metabolizing enzymes (XMEs), which are target genes of the AhR. Although these XMEs are important in the metabolism and clearance of most PAHs [8], XMEs are often ineffective in the metabolism of many HAHs-particularly chlorinated HAHs. Chlorinated HAHs, also known as dioxin-like compounds, can be sub-divided into three classes: polychlorinated biphenyls (PCBs), polychlorinated dibenzofurans (PCDFs) and polychlorinated dibenzodioxins (PCDDs).

The best known AhR ligand is TCDD, which belongs to the PCDD class. TCDD is a colorless and odorless solid whose chemical structure is characterized by the presence of a central oxygenated ring surrounded by two benzene rings. TCDD has one of the highest binding affinities of known AhR ligands- in the $\mathrm{pM}$ to $\mathrm{nM}$ range [2]. TCDD toxicity is a consequence of its chlorine substituents being located in lateral positions (on carbons 2, 3, 7 and 8), resulting in impaired metabolism and clearance. Although the exact duration of TCDD persistence will vary as a consequence of dose, exposure duration and body composition [32], the half-life of TCDD in humans ranges from approximately 7-12 years [33,34]. There have been a number of incidences whereby humans have been exposed to TCDD, including those related to occupations involving chemical and pesticide production. Accidental environmental contaminations to petrochemicals and industrial waste have also been reported [35]. Two well-characterized examples of human exposure to TCDD come from individuals subjected to 
the herbicide Agent Orange during the US-Vietnam war [36] and from the poisoning of the former Ukrainian President Viktor Yushenko [37]. Hallmark clinical manifestations of TCDD-induced toxicity in humans are hepatotoxicity; epidermal symptoms including chloracne and hyperpigmentation; cancers of the breast, lung and liver as well as immunosuppression [38]. Findings in animal models indicate that these deleterious health effects are mediated by the AhR $[18,39,40]$.

In addition to PAHs and HAHs, several classes of naturally-occurring exogenous AhR ligands have been recently described, including bacterial products and compounds derived from a healthy diet. Food-derived AhR ligands typically have a lower affinity for the AhR compared to TCDD, within the $\mu \mathrm{M}$ to $\mathrm{mM}$ range [2]. Several classes of dietary AhR agonists include indole-3-carbinol derivatives found in leafy greens such as broccoli and Brussels sprouts, as well as flavonoids found in fruits and vegetables [7]. Finally, one of ways through which the AhR contributes to the defense against bacterial infection is by sensing bacterial products (i.e., virulence factors) from Pseudomonas aeruginosa [P. aeruginosa] and Mycobacterium tuberculosis [M. tuberculosis], which function as AhR agonists [41].

\subsubsection{Endogenous AhR Agonists}

In addition to exogenous AhR agonists, there are several classes of endogenous AhR agonists. These include heme derivatives such as bilirubin and biliverdin and arachidonic acid metabolites such as prostaglandins and leukotrienes [2,7]. Although several prostaglandins have been reported to activate the $\mathrm{AhR}\left(\mathrm{PGB}_{2}, \mathrm{PGD}_{2}, \mathrm{PGF}_{3 \alpha}, \mathrm{PGG}_{2}, \mathrm{PGH}_{1}\right.$ and $\left.\mathrm{PGH}_{2}\right)$, prostaglandins and heme-derivatives are considered low-affinity ligands because they require $\mu \mathrm{M}$ concentrations to induce AhR activation [2,7]. In contrast, the arachidonic acid metabolite lipoxin $\mathrm{A}_{4}$ binds to the AhR and induces significant $\mathrm{AhR}$ activation in $\mathrm{nM}$ concentrations [42].

Tryptophan metabolites are another class of endogenous AhR agonists. Two well-characterized members of this class are kynurenine and 6-formylindolo (3,2-b) carbazole (FICZ). Kynurenine is produced during the first step of tryptophan metabolism, mediated by indoleamine 2,3-dioxygenase (IDO) [43], whereas FICZ is a tryptophan-derived ultraviolet (UV)-photoproduct [7]. Another endogenous AhR ligand that was first described in the pig lung is 2-(1'H-indole-3'-carbonyl)-thiazole-4-carboxylic acid methyl ester (ITE) [7]. Kynurenine (and its metabolites), FICZ and ITE are high affinity endogenous agonists that cause AhR activation in $\mathrm{pM}$ to nM concentrations $[2,7,44]$.

\subsection{AhR Signaling Pathways}

\subsubsection{Canonical AhR Signaling}

In the absence of ligands, the AhR is located in the cytoplasm and stably complexed with a heat shock protein 90 (HSP90) homodimer, immunophilin-like X-associated protein 2 (XAP2) and the co-chaperone p23 [7,45]. In this core complex, HSP90 ensures proper folding of newly-synthesized AhR protein [46]. XAP2 (also known as ARA9 or AhR-interacting protein [AIP]) stabilizes the unligated AhR, resulting in heightened AhR expression and transcriptional activity [46]. The role of p23 is to prevent degradation of the unligated $\mathrm{AhR}$, as supported by findings that a down-regulation of p23 results in increased ubiquitination and proteasomal degradation of the AhR protein [47]. Thus, the cumulative effect of this AhR complex is to stabilize the cytoplasmic AhR protein.

When in the cytoplasm, AhR ligands bind to the ligand-binding domain located on the amino terminus of the AhR protein. After ligand binding, the AhR core complex translocates from the cytoplasm to the nucleus. This ligand-induced AhR nuclear translocation is mediated by the dephosphorylation of two protein kinase $C$ sites found on serine 12 and 36, which are located upstream of the AhR nuclear localization signal (NLS) [48,49]. In the nucleus, the AhR dissociates from its chaperone proteins [50,51] prior to heterodimerization with the aryl hydrocarbon receptor nuclear translocator (ARNT). This AhR-ARNT complex binds to the dioxin response element (DRE), also known as the xenobiotic response element (XRE) or the aromatic hydrocarbon response element 
(AhRE) (Figure 1). The DRE has a core sequence of $5^{\prime}$-TNGCGTG-3' and is located in the promoter region of AhR target genes, the prototype of which is cytochrome P450 (CYP) CYP1A1 [52]. There are eight DREs located within the murine CYP1A1 promoter [52]. Once the AhR-ARNT complex is bound to the DRE, transcriptional co-activators facilitate the recruitment of RNA polymerase II to this complex, resulting in the initiation of transcription of AhR target genes [53]. Following the transcriptional induction of AhR target genes, the AhR dissociates from ARNT and is shuttled back to the cytoplasm via unmasking of its nuclear export signal [48]. The AhR protein is then degraded by the $26 \mathrm{~S}$ ubiquitin-proteasome system [54]. Activation of the AhR also initiates the transcription of the AhR repressor (AhRR), which functions as a negative regulator of AhR activity. The AhRR can negatively regulate AhR activity by directly interfering with AhR-ARNT interactions, which reduces AhR activity and facilitates AhR protein degradation [55]. In addition to the AhRR, TCDD-inducible Poly ADP-Ribose Polymerase (TiPARP) is another AhR target gene that functions to negatively regulate AhR activity by modulating AhR expression. This is supported by experimental evidence that TiPARP over-expression results in heighted proteolytic degradation of the AhR [56].

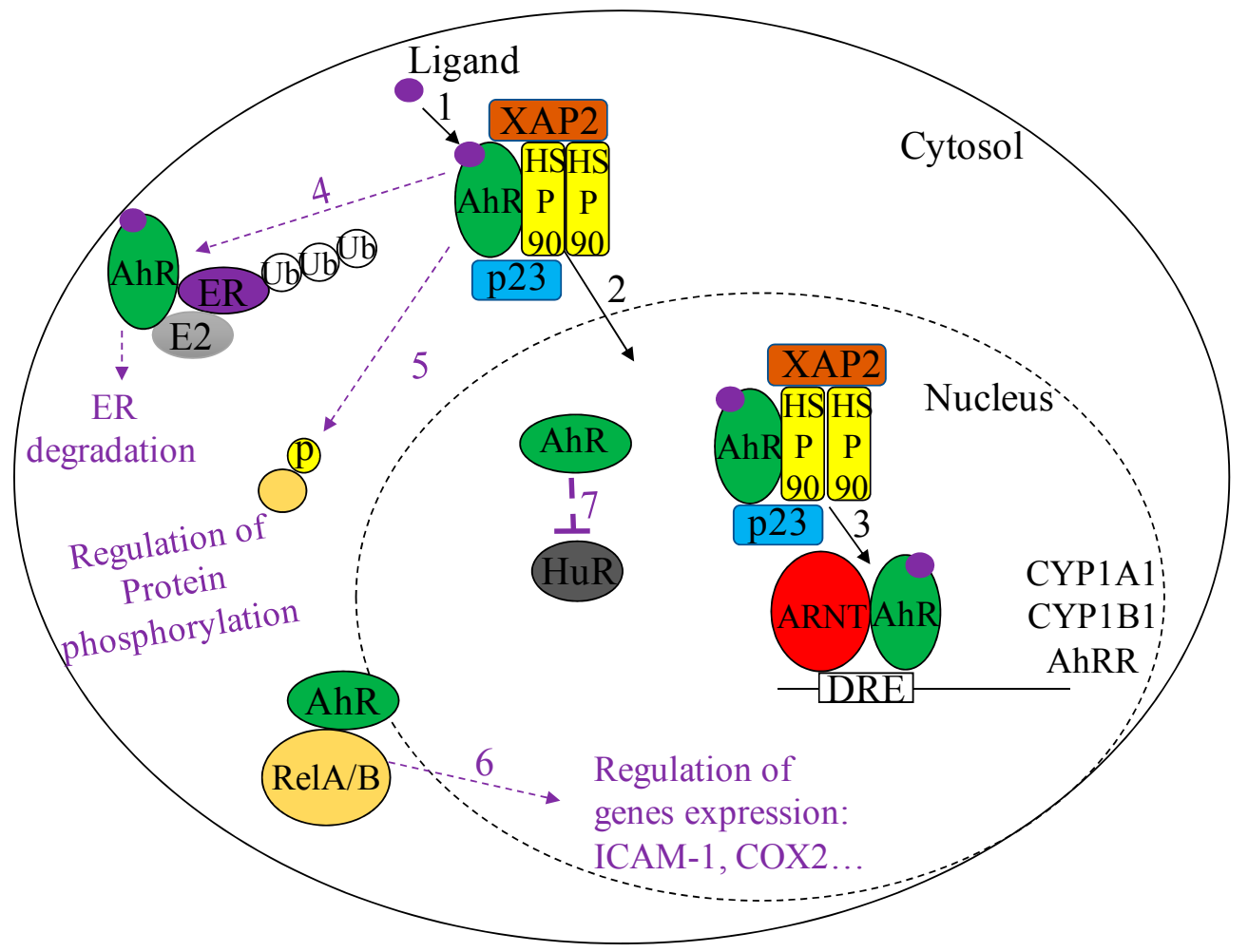

Figure 1. Diagrammatic representation of Aryl hydrocarbon receptor (AhR) signaling pathways. Canonical AhR Signaling (solid black arrows)-Inactivated AhR is found in the cytosol (solid circle) complexed to a HSP90 homodimer, XAP2 and p23. (1) Ligand binding to the AhR induces the (2) translocation of the AhR complex from the cytoplasm to the nucleus (dashed circle). In the nucleus the AhR dissociates from its chaperone proteins, (3) heterodimerizes with ARNT and binds to DRE sequences to induce transcription of target genes. Non-canonical AhR Signaling (dashed purple arrows)-The AhR can heterodimerize with a variety of proteins to mediate diverse downstream effects. (4) When complexed with the estrogen receptor (ER), the AhR functions as an E3-ligase to mediate ER ubiquitination and degradation. (5) The AhR also mediates phosphorylation events, such as the phosphorylation of Akt and ERK proteins in the cytoplasm. (6) The AhR can also bind to the $\mathrm{NF} \kappa B$ family members RelA and RelB, where it can regulate the expression of pro-inflammatory mediators such as IL6, COX-2 and ICAM1. (7) The AhR can also regulate the subcellular localization of RNA-binding proteins such as HuR, thereby indirectly influencing mRNA stability and thus expression of pro-inflammatory mediators such as COX-2. 


\subsubsection{Non-Canonical AhR Signaling}

The toxic effects of the high-affinity AhR ligand TCDD are widely understood to be mediated through the canonical AhR pathway [39,40]. This pathway is characterized by (1) ligand binding to the AhR, (2) AhR nuclear translocation, (3) AhR-ARNT heterodimerization and (4) AhR binding to the DRE to induce transcription of target genes. Paradoxically, activation of the AhR by the high-affinity AhR ligands FICZ and ITE yield non-toxic effects [57,58]. One proposed explanation for differential outcomes by AhR ligands is the activation of alternative AhR signaling mechanisms, which are often collectively referred to as non-canonical AhR signaling pathways. One example of non-canonical AhR signaling is regulation of fibroblast proliferation, which may occur through a ligand-independent mechanism. Here, AhR-expressing cells-that have higher proliferation rates than AhR-deficient cells [59]-is thought to be ligand-independent because proliferation rates in AhR-expressing cells are unaffected by deletion of the AhR ligand-binding domain [59]. Furthermore, even when the ligand binding domain is absent and ligand binding to the AhR cannot occur, the AhR can still both dimerize with ARNT and induce transcription of AhR target genes [60].

Non-canonical AhR signaling can also occur through direct physical interactions with proteins not typically required for the canonical AhR pathway. The AhR can form dimers with a variety of proteins that are involved in the cell cycle, apoptosis and the immune response [61]. For example, AhR activation by TCDD initiates a physical interaction between AhR and the estrogen receptor (ER) $[62,63]$, whereby the AhR functions as an E3-ligase and mediates ER degradation [64,65]. Such AhR-dependent ER degradation demonstrates how exposure to TCDD can modulate sex hormone expression. Additionally, by forming a protein complex with the signal transducer and activator of transcription 1 (STAT1), the AhR attenuates lipopolysaccharide (LPS)-induced expression of the pro-inflammatory cytokine interleukin-6 (IL-6) in macrophages [66]. This AhR-STAT1 complex suppresses IL-6 promoter activity and thus reduces IL-6 production [66]. Finally, the AhR physically interacts with the nuclear factor kappa beta (NF- $\mathrm{kB}$ ) protein RelA, resulting in increased cellular proliferation and tumorigenesis [27]. In lung cancer cells, AhR-RelA dimers bind to a DRE-independent NF- $\mathrm{kB}$ response element in the IL-6 promoter, resulting in increased IL-6 expression [28].

Lastly, the AhR also signals non-canonically by regulating phosphorylation events in either the cytoplasm or the nucleus. For example, the AhR mediates TCDD-induced phosphorylation of Akt and ERK [67]. This phosphorylation is unaffected by ablation of the AhR NLS, suggesting that this occurs in the cytoplasm [67]. However, the AhR also promotes phosphorylation events in the nucleus. For example, the AhR-mediates the recruitment of the inhibitor of nuclear factor kappa beta kinase subunit alpha $(\mathrm{IKK} \alpha)$ to the promoter of AhR target genes, resulting in the phosphorylation of histone 3 at serine 10 (H3S10) within the DNA [68]. This phosphorylation event is required for TCDD-induced upregulation of AhR target genes such as Cyp1a1 [68]. Both the AhR-mediated recruitment of IKK $\alpha$, and the subsequent phosphorylation event, represent non-genomic roles for the AhR that ultimately contribute to enhanced transcriptional (i.e., canonical) AhR signaling. This highlights the inter-related nature of the various modes of AhR signaling.

\subsection{Physiological Functions of the AhR}

Initiation of an AhR signaling pathway(s) is important for the regulation of diverse downstream physiological processes. Several of these processes include xenobiotic metabolism, organ development and immunity.

\subsubsection{Xenobiotic Metabolism}

The AhR promotes the upregulation of many XMEs. The first-identified members of the AhR gene battery are XMEs including CYP1A1, CYP1A2, NAD $(\mathrm{P}) \mathrm{H}$ quinone oxidoreductase 1 (NQO1), aldehyde dehydrogenase (ALDH) ALDH3a1, UDP-glucuronosyltransferase (UGT) UGT1a6 and glutathione s-transferase (GST) GSTa1 [69]. XMEs render hydrophobic substances water soluble to facilitate 
their elimination. In addition to xenobiotics, XMEs also metabolize endogenous substances such as eicosanoids, including prostaglandins and leukotrienes [70].

The CYP enzymes are Phase I XMEs that catalyze the addition, or the unmasking, of a polar functional group (e.g., $-\mathrm{OH},-\mathrm{SH},-\mathrm{NH}_{2}$ ), which can result in the formation of an active metabolite. Induction of CYP enzymes, especially CYP1A1, is typically used as evidence of AhR activation [71,72]. NQO1, ALDH3a1, UGT1a6 and GSTa1 are Phase II XMEs [73]. Phase II reactions increase water solubility of the xenobiotic via the conjugation of polar subgroups, leading to the formation of an inactive metabolite that is subsequently excreted [74]. Small lipophobic metabolites are typically excreted via the kidney into the urine, whereas larger and more lipophilic metabolites are preferentially excreted by the liver into the bile and subsequently into fecal matter [75]. Although not the predominant route of excretion, many xenobiotics (particularly gases, vapors and highly lipophilic xenobiotics) are eliminated via the lungs [76].

\subsubsection{Organ Development}

The AhR is necessary for proper organ development. AhR-deficient mice have reduced liver weight and hepatic ductal fibrosis [77]. Similarly, AhR activity in both endothelial and hematopoietic cells is necessary for vascular development and the closure of the ductus venosus [78]. The ductus venosus is a fetal structure that typically closes after birth and serves to redirect oxygenated blood coming from the placenta away from the fetal liver and towards the inferior vena cava of the fetal heart. Persistence of a patent ductus venosus after birth is associated with liver disease in adults [79]. Both AhR-deficient and TCDD-exposed AhR-expressing mice exhibit defects in cardiac development and function [80], suggesting that homeostatic regulation of AhR expression and/or activity is necessary for proper cardiac development.

The AhR may also contribute to the development of the central nervous system (CNS), as recently reviewed in this Journal [81]. AhR-deficient Caenorhabditis elegans (C. elegans) exhibit impairments in neuronal migration, differentiation and axonal branching [82]. Additionally, AhR ablation also results in cognitive defects in the murine hippocampus leading to reduced fear memory [83] and abnormal ocular movements [84]. Visual impairments observed in AhR-deficient mice may be a consequence of optic nerve demyelination and thus defective signal transduction. AhR ablation causes altered myelin composition and an increased proportion of demyelinated axons in the optic nerve [85]. Interestingly, models utilizing constitutively active AhR demonstrate that over-activation of the AhR elicits outcomes similar to AhR deficiency, as constitutive AhR activation also impairs neuronal migration in both the hippocampus and olfactory bulb [86,87]. It appears that homeostatic levels of AhR expression/activity are also critical for CNS development.

\subsubsection{Immunity}

The AhR protects organs from foreign invaders via its influence in both the innate and adaptive branches of the immune system. In the context of the innate immune system, the AhR promotes endotoxin tolerance, thereby dampening the pathologic effects of infection on the host [88]. The AhR also regulates different branches of adaptive immunity. In the humoral arm of the adaptive immune system, the AhR is critical for optimal levels of both B-cell proliferation [23] and differentiation (i.e., differentiation into antibody-secreting plasma B-cells versus memory B-cells) [89]. In respect to T-cell mediated immunity, the AhR controls the differentiation of both helper T lymphocytes (Th17) and regulatory $\mathrm{T}$ lymphocytes (Tregs) through both direct and indirect mechanisms in a context specific manner [90]. One direct mechanism may be via methylation changes. This is supported by a report demonstrating that an AhR-mediated promotion of Treg differentiation and prevention of Th17 differentiation is mechanistically mediated by Foxp3 promoter demethylation and IL-17 promoter hypermethylation, respectively [91]. An indirect mechanism through which the AhR may influence Th17 levels is via the regulation of the gut microbiome. For example, AhR-deficient mice have an increased abundance of Verrucomicrobiota and segmented filamentous bacteria in the 
gut, which is directly linked to elevated intestinal inflammation and heightened IL17a expression, suggesting a promotion of Th17 differentiation [92]. The differential outcome of Treg versus Th17 cell differentiation is also controlled by different AhR ligands. For example, kynurenine causes AhR-dependent production of Tregs whereas AhR activation by FICZ leads to the production of Th17 cells [43].

\section{The AhR in CS-Induced Lung Disease}

\subsection{Lung Cancer}

Lung cancer is the leading cause of cancer-related deaths worldwide (WHO). The role of the AhR in the promotion of lung cancer pathogenesis was recently reviewed [31], therefore it will only be briefly discussed here. Lung cancer is associated with AhR over-expression [29]. Over-expression or constitutive activation of $\mathrm{AhR}$ in cancer cell lines promotes tumor growth, whereas AhR inhibition in cancer cells leads to reduced cell proliferation and migration [30]. A pro-oncogenic role for AhR over-expression in lung cancer may be a consequence of an AhR-dependent promotion of cell proliferation [23,24], cell-cycle progression, cell migration [25] and cell survival [26]. Mechanistically, the AhR-dependent promotion of several pro-oncogenic signaling pathways (e.g., JAK2-Src interaction) is independent of the transcriptional activities of the AhR, suggesting the involvement of non-canonical AhR signaling in the promotion of lung cancer progression [67].

\subsection{Chronic Obstructive Pulmonary Disease (COPD)}

COPD is a respiratory illness characterized by progressive and irreversible air flow obstruction. Worldwide, COPD affects an estimated 380 million people [93] and is the third leading cause of death. Although often referred to as a "disease", COPD encompasses a spectrum of disorders with two predominant phenotypes: chronic bronchitis and emphysema. Chronic bronchitis predominantly affects the airways and is characterized by mucus hypersecretion, which functionally leads to airway obstruction and a productive cough [94]. In contrast, emphysema is an anatomical condition characterized by the permanent destruction of the alveolar walls, resulting in parenchymal destruction $[95,96]$. Despite the fact that chronic bronchitis and emphysema can present independently of one another, it is now widely accepted that most cases of COPD typically fall somewhere in the middle of a "COPD-spectrum" and individuals with COPD often exhibit characteristics of both chronic bronchitis and emphysema to varying extents [94].

Although COPD is predominantly caused by CS, other environmental risk factors include inhalational exposure to ambient (e.g., air pollution) and occupational (e.g., coal mines and pulp and paper manufacturing) toxicants [97-101]. Moreover, only 15-20\% of smokers go on to develop COPD, indicating that factors beyond exposure to inhalational toxicants are important. This includes genetic factors [102,103]. The only established genetic risk factor for COPD is alpha-1 antitrypsin (AAT) deficiency [104], which occurs in 3-10\% of individuals with COPD [105,106]. However, COPD is a heterogenous disease with many interrelated pathogenic mechanisms including inflammation, oxidative stress and cell death; there is also a growing body of experimental evidence demonstrating that the AhR attenuates several of these mechanisms that ultimately contribute to the development of this disease.

\subsubsection{Inflammation}

Cigarette smoking promotes pulmonary inflammation in that the number and proportion of immune cells in the lung shifts in response to CS exposure. Human cigarette smokers have heightened levels of pulmonary neutrophils, macrophages and CD8 $8^{+}$T-lymphocytes [107]. These cell types are also increased in mice exposed to CS [108]. In COPD subjects, the quantity of these cell types are further increased compared to smokers without COPD [109]. Although macrophages and CD8 ${ }^{+}$ T-lymphocytes are the predominant inflammatory cell types in the lungs of humans with COPD, 
neutrophilia is also common [110]. Elevated neutrophil numbers are also seen in the bronchoalveolar lavage (BAL) of mice exhibiting a COPD-like phenotype [111].

Neutrophils are the first immune cell type recruited to the lung in response to CS, exhibiting a significant increase in the BAL after only 3-days of CS exposure [108]. AhR-deficient mice exhibit significantly greater neutrophilia than AhR-expressing mice following both an acute (3 day) [112] and extended (2-4 week) CS exposure [11,12], indicating a role for the AhR in attenuating this early CS-induced neutrophilic response. The mechanism by which this occurs is incompletely understood. One possibility involves the AhR-dependent regulation of the NF- $\mathrm{kB}$ protein RelB. The AhR physically interacts with RelB $[113,114]$. Moreover, AhR-deficient mice exhibit a more rapid degradation of pulmonary RelB protein following CS exposure than that observed in CS-exposed AhR-expressing mice [112]. Increased RelB degradation in AhR-deficient mice is associated with increased expression of the neutrophil adhesion protein ICAM1 and heightened neutrophil infiltration [112]. These findings suggest the possibility that the AhR may attenuate CS-induced neutrophilia via a non-canonical protein interaction with RelB.

CS-induced macrophage and lymphocyte pulmonary infiltration is delayed relative to neutrophils. Significant increases of macrophage and lymphocyte numbers in the murine BAL occurs after approximately 10-days of CS exposure, whereas significant increases in the lung parenchyma is only observed after several months of CS exposure [108]. The longest in vivo CS exposure that has been reported using AhR-deficient and AhR-expressing mice is 4-weeks [11]. Based on this study, it appears that CS-induced macrophage and lymphocyte infiltration in the murine lung is independent of the AhR because although this CS duration induces a significant increase in the number of BAL macrophages and lymphocytes, this increase is independent of AhR expression [11].

The pro-inflammatory enzyme cyclooxygenase-2 (COX-2) is robustly induced in response to CS exposure [115] and is elevated in COPD subjects [10]. COX-2 may contribute to COPD pathogenesis because it initiates the downstream production of several classes of inflammatory mediators such as prostacyclins, prostaglandins (PG) and thromboxanes [116]. Experimentally, inhibition of COX-2 expression (and the downstream COX-2 product $\mathrm{PGE}_{2}$ ) using celecoxib attenuates the development of CS-induced airspace enlargement in the rat lung [117]. The AhR-mediated regulation of RelB may attenuate other aspects of CS-induced inflammation, such as the production of COX-2. In support of this, RelB reduces the expression of COX-2 [115]. Another non-canonical AhR-protein interaction that may contribute to the AhR attenuation of CS-induced inflammation is its regulation of Human Antigen $\mathrm{R}(\mathrm{HuR}) . \mathrm{HuR}$ is an RNA-binding protein that functions to stabilize target mRNA when localized to the cytoplasm, thereby promoting mRNA translation into protein. Cox2 is a target mRNA of the HuR [10]. The AhR attenuates CS-induced COX-2 expression via the nuclear sequestration of HuR, resulting in the destabilization and degradation of Cox 2 mRNA in vitro [10]. This resulted in reduced Cox 2 mRNA and protein expression in AhR-expressing cells [10]. The AhR may therefore represent a physiological regulatory mechanism to limit COX-2 overexpression. This is supported by evidence that COX-2 products, such as prostaglandins, act as AhR agonists [118] and the activated AhR then functions to attenuate CS-induced COX-2 production [10].

\subsubsection{Oxidative Stress}

Oxidative stress is another mechanism linked to COPD pathogenesis [119]. In the healthy lung, reactive oxygen species (ROS)- such as superoxide anions, hydroxyl radicals and hydrogen peroxideare counterbalanced by the production of endogenous antioxidants, including superoxide dismutase (SOD), catalase (CAT) and the glutathione (GSH)/glutathione peroxidase system [120]. When ROS production exceeds the capabilities of these antioxidant defenses, oxidative stress ensues. Inhalational exposure to CS results in heightened ROS production in the lungs, as approximately $10^{17}$ oxidant molecules are produced with each puff of a cigarette [121]. Additionally, ROS production by recruited immune cells (e.g., neutrophils and macrophages) represent another major oxidant source [120]. Cigarette smokers exhibit oxidative stress-induced lipid peroxidation [122] and reduced antioxidant 
capacities (e.g., reduced SOD and CAT activity [123]). There is evidence to support that AhR attenuates CS-induced oxidative stress. CS-exposed AhR-deficient lung structural cells exhibit significantly higher ROS production compared to CS-exposed AhR-expressing cells [9]. Additionally, AhR-deficient mouse lung fibroblasts (MLFs) also exhibit an impaired induction of the antioxidants sulfiredoxin 1 (Srxn1) and NADPH: quinone acceptor oxidoreductase 1 (Nqo1) following in vitro exposure to CS relative to AhR-expressing MLFs [9].

However, factors other than strictly CS likely contribute to the oxidative stress observed in COPD. In support of this, greater lipid peroxidation is observed in individuals with COPD that have never smoked relative to subjects without COPD [124]. Moreover, COPD subjects also have significantly reduced antioxidant expression (e.g., SOD and GSH levels) relative to smokers without COPD [125]. Reduced AhR expression in COPD-derived lung structural cells [9] has the potential to increase oxidative stress in the COPD lung. Consistent with this notion, AhR-deficient MLFs exhibit reduced expression of the antioxidants SOD1 and SOD2 relative to AhR-expressing MLFs at baseline [20]. This illustrates that AhR ablation is associated with a diminished expression of antioxidants that are necessary to combat oxidative stress.

\subsubsection{Loss of Lung Structural Cells}

A hallmark of the emphysema component of COPD is the loss of lung structural cells [126-128]. This includes loss of alveolar epithelial cells responsible for gas exchange and fibroblasts that synthesize the extracellular matrix necessary for lung structure and elasticity. CS induces apoptotic cell death in all major lung structural cell types, including bronchial and alveolar epithelial cells, fibroblasts, endothelial cells and airway smooth muscle cells [129-133]. Furthermore, humans with emphysema exhibit heightened pulmonary apoptosis [134]. Experimentally, intra-tracheal injection of the apoptotic protein cleaved caspase- 3 induces epithelial cell apoptosis and airspace enlargement in the murine lung [126], consistent with the notion that lung parenchymal destruction is linked to cell death.

The AhR has the potential to contribute to loss of structural cells in several ways. CS-exposed AhR-deficient lung structural cells exhibit significantly more apoptosis [20]. Mechanistically, attenuation of CS-induced apoptosis in vitro is mediated by the AhR-dependent regulation of miR-196a [135]. Another mechanism may be that loss of lung structural cells in the COPD lung is due to decreased replacement of lost cells. AhR-deficient cells exhibit reduced cellular proliferation relative to AhR-expressing cells [136]. This is similar to the reduced proliferative capacity of lung fibroblasts from subjects with emphysema $[137,138]$. Cellular senescence may also contribute to loss of lung structural cells in COPD, as it is increased in alveolar epithelial cells from subjects with emphysema and is also positively correlated with more severe airflow obstruction [139]. Interestingly, cultured AhR-deficient mouse embryonic fibroblasts (MEFs) reach a state of senescence more rapidly than AhR-expressing MEFs [140]. Collectively, these findings suggest that the AhR may attenuate lung parenchymal destruction by promoting conditions that reduce the loss of lung structural, including altering cell death, proliferative capacities and/or cellular senescence.

\subsubsection{Exacerbations}

Another important clinical feature of COPD is the occurrence of exacerbations, which are bouts of worsened symptoms that negatively impact quality of life [141]. COPD exacerbations are largely believed to be from infectious agents [142], particularly bacterial in origin [143]. The AhR is implicated in attenuating several bacterial lung infections of relevance to COPD exacerbations. Two of the most commonly-isolated bacteria associated with COPD exacerbations are Streptococcus pneumoniae (reported in 10-15\% of cases) and P. aeruginosa (reported in 5-10\% of cases) [144]. Experimental evidence has demonstrated that following challenge with S. pneumoniae, AhR activation by the exogenous ligand TCDD reduces lung bacterial burden and increases survival [145]. The AhR also helps maintain host defense against $P$. aeruginosa. AhR-deficiency results in increased lung bacterial burden and reduced mortality following P. aeruginosa infection relative to AhR-expressing mice [41]. 
Mechanistically, the AhR may contribute to a coordinated immune response against $P$. aeruginosa by sensing bacterially produced virulence factors (e.g., pyocyanin), which act as AhR agonists to induce an AhR-mediated production of the neutrophil chemoattractant IL-8 [146] and the subsequent recruitment of neutrophils [41].

\section{Conclusions}

Taken together, there is sufficient evidence to speculate that the AhR may lessen the susceptibility to COPD pathogenesis by attenuating CS-induced pulmonary inflammation, oxidative stress, lung structural cell loss and bacterial infections that can trigger exacerbations (Figure 2). The current body of literature regarding the AhR demonstrates the complexity and often contradictory nature of this signaling pathway and mechanisms associated with disease pathogenesis such as apoptosis, proliferation and senescence. For example, both DRE/XRE binding by ligand-bound AhR as well as AhR-deficiency inhibits cell cycle progression by upregulating p27 KIP1 [24,147-150]. Similarly, absence of the AhR as well as exposure to AhR ligands can increase cellular apoptosis [20,151-154]. These disparities raise an important lingering question: how can the AhR mediate protective effects in some contexts and pathogenic effects in others? Because a key event in AhR-mediated signaling is prolonged AhR degradation following ligand binding [155,156], it is possible that AhR-mediated pathogenicity versus protection in response to TCDD versus CS, respectively, is a consequence of the chronicity of AhR activation- and therefore degradation. This possibility is further strengthened by observations that although TCDD, FICZ and ITE are all high affinity AhR agonists [2], FICZ and ITE are rapidly metabolized and likely non-toxic [157], whereas TCDD is persistent and regarded as highly toxic. Another potential explanation is that there are additional ligand-dependent differences can mediate both pathogenic and protective effects of the AhR in a cell- or context-specific manner. For example, although it is well-established that TCDD-induced pathogenicity is mediated through the canonical AhR signaling pathway, many of the reported protective effects of the AhR against CS-induced lung injury are mediated through non-canonical AhR signaling mechanisms [9-12,135]. Although there remain disparities in our understanding of AhR signaling, the existing body of literature supports that the AhR is necessary for the maintenance of lung health. 


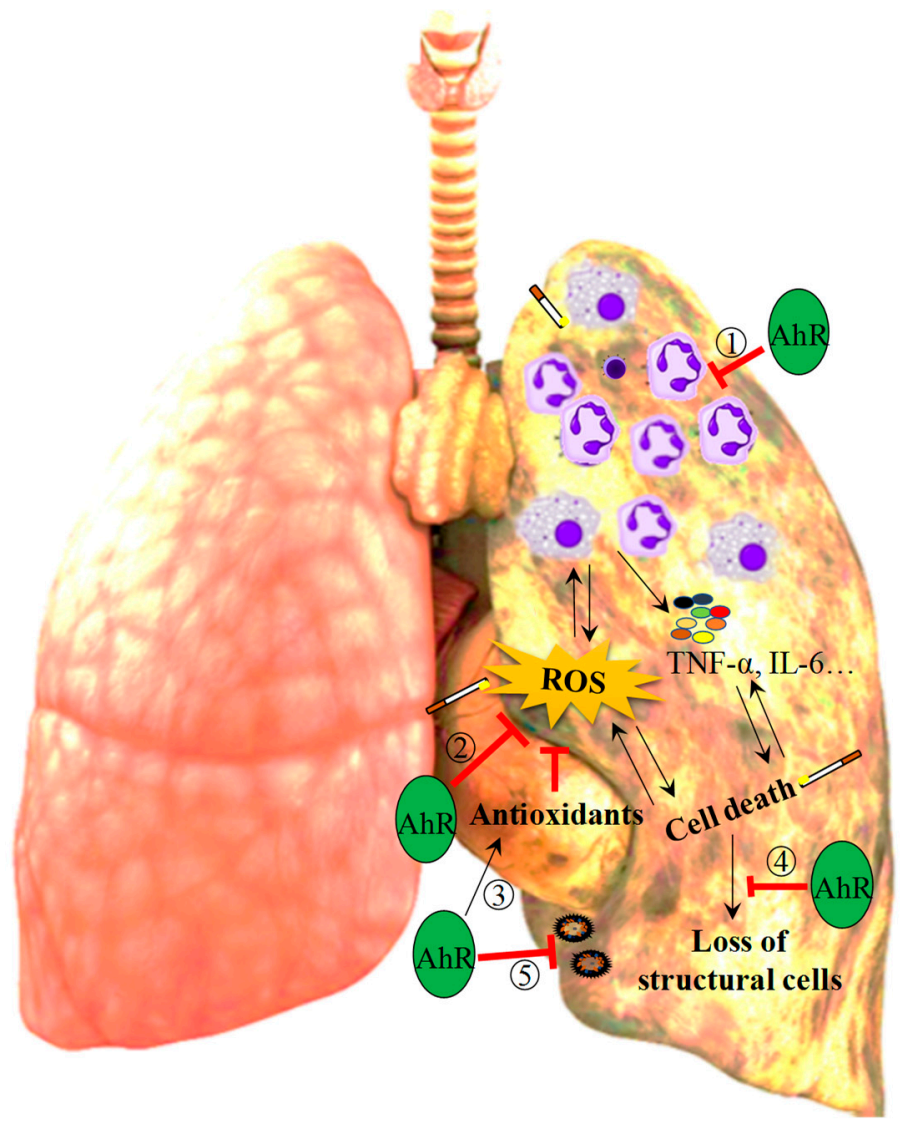

Figure 2. The AhR exerts protective effects in the lungs by attenuating CS-induced lung injury. The AhR attenuates an inter-connected web of pathogenic mechanisms that have been independently established to contribute to the progression of COPD. More specifically, the AhR may contribute to the attenuation of CS-induced inflammation via its role in (1) suppressing CS-induced pulmonary neutrophilia. Additionally, the AhR may attenuate CS-induced oxidative stress via its role in (2) suppressing CS-induced ROS production and (3) promoting the upregulation of anti-oxidants in response to CS. The AhR may also protect against CS-induced lung parenchymal destruction through its ability to (4) reduce the loss of lung structural cells by promoting cellular proliferation and attenuating CS-induced apoptosis and cellular senescence. (5) Finally, the AhR may protect the lungs against bacterial infections that could otherwise trigger COPD-associated exacerbations, such as S. Pneumoniae and $P$. aeruginosa, by promoting neutrophil infiltration. Black arrows represent promotion and red bars represent inhibition.

Author Contributions: Manuscript writing, review and editing: N.G., H.T., D.H.E., C.J.B.; Funding acquisition: D.H.E., C.J.B.

Funding: This work was supported by the Canada Foundation for Innovation (CFI), Natural Sciences and Engineering Research Council of Canada (NSERC) and the Canadian Institutes for Health Research (CIHR). C.J.B. was supported by a salary award from the Fonds de recherche du Quebec-Sante (FRQ-S).

Conflicts of Interest: The authors declare that they have no conflicts of interests.

\section{References}

1. Williams, E.G.; Mouchiroud, L.; Frochaux, M.; Pandey, A.; Andreux, P.A.; Deplancke, B.; Auwerx, J. An evolutionarily conserved role for the aryl hydrocarbon receptor in the regulation of movement. PLoS Genet. 2014, 10, e1004673. [CrossRef] [PubMed]

2. Esser, C.; Rannug, A. The aryl hydrocarbon receptor in barrier organ physiology, immunology, and toxicology. Pharmacol. Rev. 2015, 67, 259-279. [CrossRef] [PubMed] 
3. Nebert, D.W. Aryl hydrocarbon receptor (AHR): "pioneer member" of the basic-helix/loop/helix per-Arnt-sim (bHLH/PAS) family of "sensors" of foreign and endogenous signals. Prog. Lipid Res. 2017, 67, 38-57. [CrossRef] [PubMed]

4. Jones, S. An overview of the basic helix-loop-helix proteins. Genome Biol. 2004, 5, 226. [CrossRef] [PubMed]

5. Ramadoss, P.; Perdew, G.H. The transactivation domain of the Ah receptor is a key determinant of cellular localization and ligand-independent nucleocytoplasmic shuttling properties. Biochemistry 2005, 44, 11148-11159. [CrossRef] [PubMed]

6. Stevens, E.A.; Mezrich, J.D.; Bradfield, C.A. The aryl hydrocarbon receptor: A perspective on potential roles in the immune system. Immunology 2009, 127, 299-311. [CrossRef] [PubMed]

7. Nguyen, L.P.; Bradfield, C.A. The search for endogenous activators of the aryl hydrocarbon receptor. Chem. Res. Toxicol. 2008, 21, 102-116. [CrossRef]

8. Stejskalova, L.; Dvorak, Z.; Pavek, P. Endogenous and exogenous ligands of aryl hydrocarbon receptor: Current state of art. Curr. Drug Metab. 2011, 12, 198-212. [CrossRef]

9. Sarill, M.; Zago, M.; Sheridan, J.A.; Nair, P.; Matthews, J.; Gomez, A.; Roussel, L.; Rousseau, S.; Hamid, Q.; Eidelman, D.H.; et al. The aryl hydrocarbon receptor suppresses cigarette-smoke-induced oxidative stress in association with dioxin response element (DRE)-independent regulation of sulfiredoxin 1. Free Radic. Biol. Med. 2015, 89, 342-357. [CrossRef]

10. Zago, M.; Sheridan, J.A.; Nair, P.; Rico de Souza, A.; Gallouzi, I.E.; Rousseau, S.; Di Marco, S.; Hamid, Q.; Eidelman, D.H.; Baglole, C.J. Aryl hydrocarbon receptor-dependent retention of nuclear HuR suppresses cigarette smoke-induced cyclooxygenase-2 expression independent of DNA-binding. PLoS ONE 2013, 8 , e74953. [CrossRef]

11. Rogers, S.; de Souza, A.R.; Zago, M.; Iu, M.; Guerrina, N.; Gomez, A.; Matthews, J.; Baglole, C.J. Aryl hydrocarbon receptor (AhR)-dependent regulation of pulmonary miRNA by chronic cigarette smoke exposure. Sci. Rep. 2017, 7, 40539. [CrossRef] [PubMed]

12. De Souza, A.R.; Zago, M.; Eidelman, D.H.; Hamid, Q.; Baglole, C.J. Aryl hydrocarbon receptor (AhR) attenuation of subchronic cigarette smoke-induced pulmonary neutrophilia is associated with retention of nuclear RelB and suppression of intercellular adhesion molecule-1 (ICAM-1). Toxicol. Sci. 2014, 140, $204-223$. [CrossRef] [PubMed]

13. Valavanidis, A.; Fiotakis, K.; Vlachogianni, T. Airborne particulate matter and human health: Toxicological assessment and importance of size and composition of particles for oxidative damage and carcinogenic mechanisms. J. Environ. Sci. Health C Environ. Carcinog. Ecotoxicol. Rev. 2008, 26, 339-362. [CrossRef] [PubMed]

14. Ghio, A.J. Particle exposures and infections. Infection 2014, 42, 459-467. [CrossRef] [PubMed]

15. National Research Council. Review of the Department of Defence Enhanced Particulate Matter Surveillance Program Report; Defence, D.O., Ed.; The National Academies Press: Washington, DC, USA, 2010; p. 85.

16. Nemmar, A.; Holme, J.A.; Rosas, I.; Schwarze, P.E.; Alfaro-Moreno, E. Recent advances in particulate matter and nanoparticle toxicology: A review of the in vivo and in vitro studies. BioMed Res. Int. 2013, 2013, 279371. [CrossRef] [PubMed]

17. Van den Bogaard, E.H.; Bergboer, J.G.; Vonk-Bergers, M.; van Vlijmen-Willems, I.M.; Hato, S.V.; van der Valk, P.G.; Schroder, J.M.; Joosten, I.; Zeeuwen, P.L.; Schalkwijk, J. Coal tar induces AHR-dependent skin barrier repair in atopic dermatitis. J. Clin. Investig. 2013, 123, 917-927. [CrossRef] [PubMed]

18. Fernandez-Salguero, P.M.; Hilbert, D.M.; Rudikoff, S.; Ward, J.M.; Gonzalez, F.J. Aryl-hydrocarbon receptor-deficient mice are resistant to 2,3,7,8-tetrachlorodibenzo-p-dioxin-induced toxicity. Toxicol. Appl. Pharmacol. 1996, 140, 173-179. [CrossRef]

19. Shimizu, Y.; Nakatsuru, Y.; Ichinose, M.; Takahashi, Y.; Kume, H.; Mimura, J.; Fujii-Kuriyama, Y.; Ishikawa, T. Benzo[a]pyrene carcinogenicity is lost in mice lacking the aryl hydrocarbon receptor. Proc. Natl. Acad. Sci. USA 2000, 97, 779-782. [CrossRef]

20. Rico de Souza, A.; Zago, M.; Pollock, S.J.; Sime, P.J.; Phipps, R.P.; Baglole, C.J. Genetic ablation of the aryl hydrocarbon receptor causes cigarette smoke-induced mitochondrial dysfunction and apoptosis. J. Biol. Chem. 2011, 286, 43214-43228. [CrossRef]

21. Tan, W.C.; Sin, D.D.; Bourbeau, J.; Hernandez, P.; Chapman, K.R.; Cowie, R.; FitzGerald, J.M.; Marciniuk, D.D.; Maltais, F.; Buist, A.S.; et al. Characteristics of COPD in never-smokers and ever-smokers in the general population: Results from the CanCOLD study. Thorax 2015, 70, 822-829. [CrossRef]

22. Xie, A.; Croce, B.; Tian, D.H. Smoking and lung cancer. Ann. Cardiothorac. Surg. 2014, 3, 22. 
23. Villa, M.; Gialitakis, M.; Tolaini, M.; Ahlfors, H.; Henderson, C.J.; Wolf, C.R.; Brink, R.; Stockinger, B. Aryl hydrocarbon receptor is required for optimal B-cell proliferation. EMBO J. 2017, 36, 116-128. [CrossRef] [PubMed]

24. Shimba, S.; Komiyama, K.; Moro, I.; Tezuka, M. Overexpression of the aryl hydrocarbon receptor (AhR) accelerates the cell proliferation of A549 cells. J. Biochem. 2002, 132, 795-802. [CrossRef] [PubMed]

25. Yin, X.F.; Chen, J.; Mao, W.; Wang, Y.H.; Chen, M.H. Downregulation of aryl hydrocarbon receptor expression decreases gastric cancer cell growth and invasion. Oncol. Rep. 2013, 30, 364-370. [CrossRef] [PubMed]

26. Bekki, K.; Vogel, H.; Li, W.; Ito, T.; Sweeney, C.; Haarmann-Stemmann, T.; Matsumura, F.; Vogel, C.F. The aryl hydrocarbon receptor (AhR) mediates resistance to apoptosis induced in breast cancer cells. Pestic. Biochem. Physiol. 2015, 120, 5-13. [CrossRef] [PubMed]

27. Kim, D.W.; Gazourian, L.; Quadri, S.A.; Romieu-Mourez, R.; Sherr, D.H.; Sonenshein, G.E. The RelA NF-kappaB subunit and the aryl hydrocarbon receptor (AhR) cooperate to transactivate the c-myc promoter in mammary cells. Oncogene 2000, 19, 5498-5506. [CrossRef] [PubMed]

28. Chen, P.H.; Chang, H.; Chang, J.T.; Lin, P. Aryl hydrocarbon receptor in association with RelA modulates IL-6 expression in non-smoking lung cancer. Oncogene 2012, 31, 2555-2565. [CrossRef] [PubMed]

29. Lin, P.; Chang, H.; Tsai, W.T.; Wu, M.H.; Liao, Y.S.; Chen, J.T.; Su, J.M. Overexpression of aryl hydrocarbon receptor in human lung carcinomas. Toxicol. Pathol. 2003, 31, 22-30. [CrossRef]

30. Safe, S.; Lee, S.O.; Jin, U.H. Role of the aryl hydrocarbon receptor in carcinogenesis and potential as a drug target. Toxicol. Sci. 2013, 135, 1-16. [CrossRef]

31. Tsay, J.J.; Tchou-Wong, K.M.; Greenberg, A.K.; Pass, H.; Rom, W.N. Aryl hydrocarbon receptor and lung cancer. Anticancer Res. 2013, 33, 1247-1256.

32. Van Leeuwen, F.X.; Feeley, M.; Schrenk, D.; Larsen, J.C.; Farland, W.; Younes, M. Dioxins: WHO's tolerable daily intake (TDI) revisited. Chemosphere 2000, 40, 1095-1101. [CrossRef]

33. Pirkle, J.L.; Wolfe, W.H.; Patterson, D.G.; Needham, L.L.; Michalek, J.E.; Miner, J.C.; Peterson, M.R.; Phillips, D.L. Estimates of the half-life of 2,3,7,8-tetrachlorodibenzo-p-dioxin in Vietnam Veterans of Operation Ranch Hand. J. Toxicol. Environ. Health 1989, 27, 165-171. [CrossRef] [PubMed]

34. Wolfe, W.H.; Michalek, J.E.; Miner, J.C.; Pirkle, J.L.; Caudill, S.P.; Patterson, D.G., Jr.; Needham, L.L. Determinants of TCDD half-life in veterans of operation ranch hand. J. Toxicol. Environ. Health 1994, 41, 481-488. [CrossRef] [PubMed]

35. Sweeney, M.H.; Mocarelli, P. Human health effects after exposure to 2,3,7,8-TCDD. Food Addit. Contam. 2000, 17, 303-316. [CrossRef] [PubMed]

36. Armitage, J.M.; Ginevan, M.E.; Hewitt, A.; Ross, J.H.; Watkins, D.K.; Solomon, K.R. Environmental fate and dietary exposures of humans to TCDD as a result of the spraying of Agent Orange in upland forests of Vietnam. Sci. Total Environ. 2015, 506-507, 621-630. [CrossRef] [PubMed]

37. Sorg, O.; Zennegg, M.; Schmid, P.; Fedosyuk, R.; Valikhnovskyi, R.; Gaide, O.; Kniazevych, V.; Saurat, J.H. 2,3,7,8-tetrachlorodibenzo-p-dioxin (TCDD) poisoning in Victor Yushchenko: Identification and measurement of TCDD metabolites. Lancet 2009, 374, 1179-1185. [CrossRef]

38. Schecter, A.; Birnbaum, L.; Ryan, J.J.; Constable, J.D. Dioxins: An overview. Environ. Res. 2006, 101, 419-428. [CrossRef]

39. Bunger, M.K.; Glover, E.; Moran, S.M.; Walisser, J.A.; Lahvis, G.P.; Hsu, E.L.; Bradfield, C.A. Abnormal liver development and resistance to 2,3,7,8-tetrachlorodibenzo-p-dioxin toxicity in mice carrying a mutation in the DNA-binding domain of the aryl hydrocarbon receptor. Toxicol. Sci. 2008, 106, 83-92. [CrossRef]

40. Bunger, M.K.; Moran, S.M.; Glover, E.; Thomae, T.L.; Lahvis, G.P.; Lin, B.C.; Bradfield, C.A. Resistance to 2,3,7,8-tetrachlorodibenzo-p-dioxin toxicity and abnormal liver development in mice carrying a mutation in the nuclear localization sequence of the aryl hydrocarbon receptor. J. Biol. Chem. 2003, 278, 17767-17774. [CrossRef]

41. Moura-Alves, P.; Fae, K.; Houthuys, E.; Dorhoi, A.; Kreuchwig, A.; Furkert, J.; Barison, N.; Diehl, A.; Munder, A.; Constant, P.; et al. AhR sensing of bacterial pigments regulates antibacterial defence. Nature 2014, 512, 387-392. [CrossRef]

42. Schaldach, C.M.; Riby, J.; Bjeldanes, L.F. Lipoxin A4: A new class of ligand for the Ah receptor. Biochemistry 1999, 38, 7594-7600. [CrossRef] [PubMed] 
43. Mezrich, J.D.; Fechner, J.H.; Zhang, X.; Johnson, B.P.; Burlingham, W.J.; Bradfield, C.A. An interaction between kynurenine and the aryl hydrocarbon receptor can generate regulatory T cells. J. Immunol. 2010, 185, 3190-3198. [CrossRef] [PubMed]

44. Seok, S.H.; Ma, Z.X.; Feltenberger, J.B.; Chen, H.; Chen, H.; Scarlett, C.; Lin, Z.; Satyshur, K.A.; Cortopassi, M.; Jefcoate, C.R.; et al. Trace derivatives of kynurenine potently activate the aryl hydrocarbon receptor (AHR). J. Biol. Chem. 2018, 293, 1994-2005. [CrossRef] [PubMed]

45. Rowlands, J.C.; Gustafsson, J.A. Aryl hydrocarbon receptor-mediated signal transduction. Crit. Rev. Toxicol. 1997, 27, 109-134. [CrossRef] [PubMed]

46. Petrulis, J.R.; Perdew, G.H. The role of chaperone proteins in the aryl hydrocarbon receptor core complex. Chem. Biol. Interact. 2002, 141, 25-40. [CrossRef]

47. Pappas, B.; Yang, Y.; Wang, Y.; Kim, K.; Chung, H.J.; Cheung, M.; Ngo, K.; Shinn, A.; Chan, W.K. p23 protects the human aryl hydrocarbon receptor from degradation via a heat shock protein 90 -independent mechanism. Biochem. Pharmacol. 2018, 152, 34-44. [CrossRef] [PubMed]

48. Ikuta, T.; Eguchi, H.; Tachibana, T.; Yoneda, Y.; Kawajiri, K. Nuclear localization and export signals of the human aryl hydrocarbon receptor. J. Biol. Chem. 1998, 273, 2895-2904. [CrossRef]

49. Ikuta, T.; Kobayashi, Y.; Kawajiri, K. Phosphorylation of nuclear localization signal inhibits the ligand-dependent nuclear import of aryl hydrocarbon receptor. Biochem. Biophys. Res. Commun. 2004, 317, 545-550. [CrossRef]

50. McGuire, J.; Whitelaw, M.L.; Pongratz, I.; Gustafsson, J.A.; Poellinger, L. A cellular factor stimulates ligand-dependent release of hsp90 from the basic helix-loop-helix dioxin receptor. Mol. Cell. Biol. 1994, 14, 2438-2446. [CrossRef]

51. Tsuji, N.; Fukuda, K.; Nagata, Y.; Okada, H.; Haga, A.; Hatakeyama, S.; Yoshida, S.; Okamoto, T.; Hosaka, M.; Sekine, K.; et al. The activation mechanism of the aryl hydrocarbon receptor (AhR) by molecular chaperone HSP90. FEBS Open Bio 2014, 4, 796-803. [CrossRef]

52. Nukaya, M.; Moran, S.; Bradfield, C.A. The role of the dioxin-responsive element cluster between the Cyp1a1 and Cyp1a2 loci in aryl hydrocarbon receptor biology. Proc. Natl. Acad. Sci. USA 2009, 106, 4923-4928. [CrossRef] [PubMed]

53. Hestermann, E.V.; Brown, M. Agonist and chemopreventative ligands induce differential transcriptional cofactor recruitment by aryl hydrocarbon receptor. Mol. Cell. Biol. 2003, 23, 7920-7925. [CrossRef] [PubMed]

54. Davarinos, N.A.; Pollenz, R.S. Aryl hydrocarbon receptor imported into the nucleus following ligand binding is rapidly degraded via the cytosplasmic proteasome following nuclear export. J. Biol. Chem. 1999, 274, 28708-28715. [CrossRef] [PubMed]

55. Awji, E.G.; Chand, H.; Bruse, S.; Smith, K.R.; Colby, J.K.; Mebratu, Y.; Levy, B.D.; Tesfaigzi, Y. Wood smoke enhances cigarette smoke-induced inflammation by inducing the aryl hydrocarbon receptor repressor in airway epithelial cells. Am. J. Respir. Cell Mol. Biol. 2015, 52, 377-386. [CrossRef] [PubMed]

56. MacPherson, L.; Ahmed, S.; Tamblyn, L.; Krutmann, J.; Forster, I.; Weighardt, H.; Matthews, J. Aryl hydrocarbon receptor repressor and TiPARP (ARTD14) use similar, but also distinct mechanisms to repress aryl hydrocarbon receptor signaling. Int. J. Mol. Sci. 2014, 15, 7939-7957. [CrossRef] [PubMed]

57. Mulero-Navarro, S.; Fernandez-Salguero, P.M. New Trends in Aryl Hydrocarbon Receptor Biology. Front. Cell Dev. Biol. 2016, 4, 45. [CrossRef] [PubMed]

58. Nugent, L.F.; Shi, G.; Vistica, B.P.; Ogbeifun, O.; Hinshaw, S.J.; Gery, I. ITE, a novel endogenous nontoxic aryl hydrocarbon receptor ligand, efficiently suppresses EAU and T-cell-mediated immunity. Investig. Ophthalmol. Vis. Sci. 2013, 54, 7463-7469. [CrossRef]

59. Chang, X.; Fan, Y.; Karyala, S.; Schwemberger, S.; Tomlinson, C.R.; Sartor, M.A.; Puga, A. Ligand-independent regulation of transforming growth factor beta1 expression and cell cycle progression by the aryl hydrocarbon receptor. Mol. Cell. Biol. 2007, 27, 6127-6139. [CrossRef]

60. Beischlag, T.V.; Luis Morales, J.; Hollingshead, B.D.; Perdew, G.H. The aryl hydrocarbon receptor complex and the control of gene expression. Crit. Rev. Eukaryot. Gene Expr. 2008, 18, 207-250. [CrossRef]

61. Tappenden, D.M.; Hwang, H.J.; Yang, L.; Thomas, R.S.; Lapres, J.J. The Aryl-Hydrocarbon Receptor Protein Interaction Network (AHR-PIN) as Identified by Tandem Affinity Purification (TAP) and Mass Spectrometry. J. Toxicol. 2013, 2013, 279829. [CrossRef]

62. Wang, F.; Hoivik, D.; Pollenz, R.; Safe, S. Functional and physical interactions between the estrogen receptor Sp1 and nuclear aryl hydrocarbon receptor complexes. Nucleic Acids Res. 1998, 26, 3044-3052. [CrossRef] 
63. Ahmed, S.; Valen, E.; Sandelin, A.; Matthews, J. Dioxin increases the interaction between aryl hydrocarbon receptor and estrogen receptor alpha at human promoters. Toxicol. Sci. 2009, 111, 254-266. [CrossRef]

64. Ohtake, F.; Baba, A.; Takada, I.; Okada, M.; Iwasaki, K.; Miki, H.; Takahashi, S.; Kouzmenko, A.; Nohara, K.; Chiba, T.; et al. Dioxin receptor is a ligand-dependent E3 ubiquitin ligase. Nature 2007, 446, 562-566. [CrossRef] [PubMed]

65. Ohtake, F.; Fujii-Kuriyama, Y.; Kato, S. Transcription factor AhR is a ligand-dependent E3 ubiquitin ligase. Tanpakushitsu Kakusan Koso 2007, 52, 1973-1979. [PubMed]

66. Kimura, A.; Naka, T.; Nakahama, T.; Chinen, I.; Masuda, K.; Nohara, K.; Fujii-Kuriyama, Y.; Kishimoto, T. Aryl hydrocarbon receptor in combination with Stat1 regulates LPS-induced inflammatory responses. J. Exp. Med. 2009, 206, 2027-2035. [CrossRef] [PubMed]

67. Ye, M.; Zhang, Y.; Gao, H.; Xu, Y.; Jing, P.; Wu, J.; Zhang, X.; Xiong, J.; Dong, C.; Yao, L.; et al. Activation of the Aryl Hydrocarbon Receptor Leads to Resistance to EGFR TKIs in Non-Small Cell Lung Cancer by Activating Src-mediated Bypass Signaling. Clin. Cancer Res. 2018, 24, 1227-1239. [CrossRef] [PubMed]

68. Kurita, H.; Schnekenburger, M.; Ovesen, J.L.; Xia, Y.; Puga, A. The Ah receptor recruits IKKalpha to its target binding motifs to phosphorylate serine-10 in histone $\mathrm{H} 3$ required for transcriptional activation. Toxicol. Sci. 2014, 139, 121-132. [CrossRef]

69. Nebert, D.W.; Roe, A.L.; Dieter, M.Z.; Solis, W.A.; Yang, Y.; Dalton, T.P. Role of the aromatic hydrocarbon receptor and [Ah] gene battery in the oxidative stress response, cell cycle control, and apoptosis. Biochem. Pharmacol. 2000, 59, 65-85. [CrossRef]

70. Nebert, D.W.; Karp, C.L. Endogenous functions of the aryl hydrocarbon receptor (AHR): Intersection of cytochrome P450 1 (CYP1)-metabolized eicosanoids and AHR biology. J. Biol. Chem. 2008, 283, 36061-36065. [CrossRef]

71. Whitlock, J.P., Jr. Induction of cytochrome P4501A1. Annu. Rev. Pharmacol. Toxicol. 1999, 39, 103-125. [CrossRef]

72. Whitlock, J.P., Jr.; Okino, S.T.; Dong, L.; Ko, H.P.; Clarke-Katzenberg, R.; Ma, Q.; Li, H. Cytochromes P450 5: Induction of cytochrome P4501A1: A model for analyzing mammalian gene transcription. FASEB J. 1996, 10, 809-818. [CrossRef] [PubMed]

73. Kohle, C.; Bock, K.W. Coordinate regulation of Phase I and II xenobiotic metabolisms by the Ah receptor and Nrf2. Biochem. Pharmacol. 2007, 73, 1853-1862. [CrossRef] [PubMed]

74. Jancova, P.; Anzenbacher, P.; Anzenbacherova, E. Phase II drug metabolizing enzymes. Biomed. Pap. Med. Fac. Univ. Palacky Olomouc Czech Repub. 2010, 154, 103-116. [CrossRef] [PubMed]

75. Fleck, C.; Braunlich, H. Factors determining the relationship between renal and hepatic excretion of xenobiotics. Arzneimittelforschung 1990, 40, 942-946. [PubMed]

76. Caldwell, J.; Gardner, I.; Swales, N. An introduction to drug disposition: The basic principles of absorption, distribution, metabolism, and excretion. Toxicol. Pathol. 1995, 23, 102-114. [CrossRef] [PubMed]

77. Schmidt, J.V.; Su, G.H.; Reddy, J.K.; Simon, M.C.; Bradfield, C.A. Characterization of a murine Ahr null allele: Involvement of the Ah receptor in hepatic growth and development. Proc. Natl. Acad. Sci. USA 1996, 93, 6731-6736. [CrossRef] [PubMed]

78. Walisser, J.A.; Glover, E.; Pande, K.; Liss, A.L.; Bradfield, C.A. Aryl hydrocarbon receptor-dependent liver development and hepatotoxicity are mediated by different cell types. Proc. Natl. Acad. Sci. USA 2005, 102, 17858-17863. [CrossRef] [PubMed]

79. Jacob, S.; Farr, G.; De Vun, D.; Takiff, H.; Mason, A. Hepatic manifestations of familial patent ductus venosus in adults. Gut 1999, 45, 442-445. [CrossRef] [PubMed]

80. Carreira, V.S.; Fan, Y.; Wang, Q.; Zhang, X.; Kurita, H.; Ko, C.I.; Naticchioni, M.; Jiang, M.; Koch, S.; Medvedovic, M.; et al. Ah Receptor Signaling Controls the Expression of Cardiac Development and Homeostasis Genes. Toxicol. Sci. 2015, 147, 425-435. [CrossRef] [PubMed]

81. Juricek, L.; Coumoul, X. The Aryl Hydrocarbon Receptor and the Nervous System. Int. J. Mol. Sci. 2018, 19, 2504. [CrossRef]

82. Qin, H.; Powell-Coffman, J.A. The Caenorhabditis elegans aryl hydrocarbon receptor, AHR-1, regulates neuronal development. Dev. Biol. 2004, 270, 64-67. [CrossRef] [PubMed]

83. Latchney, S.E.; Hein, A.M.; O’Banion, M.K.; DiCicco-Bloom, E.; Opanashuk, L.A. Deletion or activation of the aryl hydrocarbon receptor alters adult hippocampal neurogenesis and contextual fear memory. J. Neurochem. 2013, 125, 430-445. [CrossRef] [PubMed] 
84. Chevallier, A.; Mialot, A.; Petit, J.M.; Fernandez-Salguero, P.; Barouki, R.; Coumoul, X.; Beraneck, M. Oculomotor deficits in aryl hydrocarbon receptor null mouse. PLoS ONE 2013, 8, e53520. [CrossRef] [PubMed]

85. Juricek, L.; Carcaud, J.; Pelhaitre, A.; Riday, T.T.; Chevallier, A.; Lanzini, J.; Auzeil, N.; Laprevote, O.; Dumont, F.; Jacques, S.; et al. AhR-deficiency as a cause of demyelinating disease and inflammation. Sci. Rep. 2017, 7, 9794. [CrossRef] [PubMed]

86. Kimura, E.; Ding, Y.; Tohyama, C. AhR signaling activation disrupts migration and dendritic growth of olfactory interneurons in the developing mouse. Sci. Rep. 2016, 6, 26386. [CrossRef] [PubMed]

87. Kimura, E.; Kubo, K.I.; Endo, T.; Nakajima, K.; Kakeyama, M.; Tohyama, C. Excessive activation of AhR signaling disrupts neuronal migration in the hippocampal CA1 region in the developing mouse. J. Toxicol. Sci. 2017, 42, 25-30. [CrossRef] [PubMed]

88. Bessede, A.; Gargaro, M.; Pallotta, M.T.; Matino, D.; Servillo, G.; Brunacci, C.; Bicciato, S.; Mazza, E.M.; Macchiarulo, A.; Vacca, C.; et al. Aryl hydrocarbon receptor control of a disease tolerance defence pathway. Nature 2014, 511, 184-190. [CrossRef] [PubMed]

89. Vaidyanathan, B.; Chaudhry, A.; Yewdell, W.T.; Angeletti, D.; Yen, W.F.; Wheatley, A.K.; Bradfield, C.A.; McDermott, A.B.; Yewdell, J.W.; Rudensky, A.Y.; et al. The aryl hydrocarbon receptor controls cell-fate decisions in B cells. J. Exp. Med. 2017, 214, 197-208. [CrossRef]

90. Mohinta, S.; Kannan, A.K.; Gowda, K.; Amin, S.G.; Perdew, G.H.; August, A. Differential regulation of Th17 and $\mathrm{T}$ regulatory cell differentiation by aryl hydrocarbon receptor dependent xenobiotic response element dependent and independent pathways. Toxicol. Sci. 2015, 145, 233-243. [CrossRef]

91. Singh, N.P.; Singh, U.P.; Singh, B.; Price, R.L.; Nagarkatti, M.; Nagarkatti, P.S. Activation of aryl hydrocarbon receptor (AhR) leads to reciprocal epigenetic regulation of FoxP3 and IL-17 expression and amelioration of experimental colitis. PLoS ONE 2011, 6, e23522. [CrossRef]

92. Murray, I.A.; Nichols, R.G.; Zhang, L.; Patterson, A.D.; Perdew, G.H. Expression of the aryl hydrocarbon receptor contributes to the establishment of intestinal microbial community structure in mice. Sci. Rep. 2016, 6, 33969. [CrossRef] [PubMed]

93. Adeloye, D.; Chua, S.; Lee, C.; Basquill, C.; Papana, A.; Theodoratou, E.; Nair, H.; Gasevic, D.; Sridhar, D.; Campbell, H.; et al. Global and regional estimates of COPD prevalence: Systematic review and meta-analysis. J. Glob. Health 2015, 5, 020415. [CrossRef] [PubMed]

94. Kim, V.; Criner, G.J. Chronic bronchitis and chronic obstructive pulmonary disease. Am. J. Respir. Crit. Care Med. 2013, 187, 228-237. [CrossRef] [PubMed]

95. Berg, K.; Wright, J.L. The Pathology of Chronic Obstructive Pulmonary Disease: Progress in the 20th and 21st Centuries. Arch. Pathol. Lab. Med. 2016, 140, 1423-1428. [CrossRef] [PubMed]

96. Kemp, S.V.; Polkey, M.I.; Shah, P.L. The epidemiology, etiology, clinical features, and natural history of emphysema. Thorac. Surg. Clin. 2009, 19, 149-158. [CrossRef] [PubMed]

97. Andersen, Z.J.; Kristiansen, L.C.; Andersen, K.K.; Olsen, T.S.; Hvidberg, M.; Jensen, S.S.; Ketzel, M.; Loft, S.; Sorensen, M.; Tjonneland, A.; et al. Stroke and long-term exposure to outdoor air pollution from nitrogen dioxide: A cohort study. Stroke 2012, 43, 320-325. [CrossRef]

98. DeVries, R.; Kriebel, D.; Sama, S. Low level air pollution and exacerbation of existing copd: A case crossover analysis. Environ. Health 2016, 15, 98. [CrossRef]

99. Hu, G.; Zhou, Y.; Tian, J.; Yao, W.; Li, J.; Li, B.; Ran, P. Risk of COPD from exposure to biomass smoke: A metaanalysis. Chest 2010, 138, 20-31. [CrossRef]

100. Santo Tomas, L.H. Emphysema and chronic obstructive pulmonary disease in coal miners. Curr. Opin. Pulm Med. 2011, 17, 123-125. [CrossRef]

101. Thoren, K.; Jarvholm, B.; Morgan, U. Mortality from asthma and chronic obstructive pulmonary disease among workers in a soft paper mill: A case-referent study. Br. J. Ind. Med. 1989, 46, 192-195. [CrossRef]

102. Busch, R.; Hobbs, B.D.; Zhou, J.; Castaldi, P.J.; McGeachie, M.J.; Hardin, M.E.; Hawrylkiewicz, I.; Sliwinski, P.; Yim, J.J.; Kim, W.J.; et al. Genetic Association and Risk Scores in a Chronic Obstructive Pulmonary Disease Meta-analysis of 16,707 Subjects. Am. J. Respir. Cell Mol. Biol. 2017, 57, 35-46. [CrossRef] [PubMed]

103. Hancock, D.B.; Eijgelsheim, M.; Wilk, J.B.; Gharib, S.A.; Loehr, L.R.; Marciante, K.D.; Franceschini, N.; van Durme, Y.M.; Chen, T.H.; Barr, R.G.; et al. Meta-analyses of genome-wide association studies identify multiple loci associated with pulmonary function. Nat. Genet. 2010, 42, 45-52. [CrossRef] [PubMed] 
104. Seifart, C.; Plagens, A. Genetics of chronic obstructive pulmonary disease. Int. J. Chron. Obstr. Pulm. Dis. 2007, 2, 541-550.

105. Lieberman, J.; Winter, B.; Sastre, A. Alpha 1-antitrypsin Pi-types in 965 COPD patients. Chest 1986, 89, 370-373. [CrossRef] [PubMed]

106. Russo, R.; Zillmer, L.R.; Nascimento, O.A.; Manzano, B.; Ivanaga, I.T.; Fritscher, L.; Lundgren, F.; Miravitlles, M.; Gondim, H.D.; Santos, G.J.; et al. Prevalence of alpha-1 antitrypsin deficiency and allele frequency in patients with COPD in Brazil. J. Bras. Pneumol. 2016, 42, 311-316. [CrossRef] [PubMed]

107. Tamimi, A.; Serdarevic, D.; Hanania, N.A. The effects of cigarette smoke on airway inflammation in asthma and COPD: Therapeutic implications. Respir. Med. 2012, 106, 319-328. [CrossRef] [PubMed]

108. D’Hulst A, I.; Vermaelen, K.Y.; Brusselle, G.G.; Joos, G.F.; Pauwels, R.A. Time course of cigarette smoke-induced pulmonary inflammation in mice. Eur. Respir. J. 2005, 26, 204-213. [CrossRef]

109. MacNee, W. Pathogenesis of chronic obstructive pulmonary disease. Proc. Am. Thorac. Soc. 2005, 2, 258-266, discussion 290-251. [CrossRef]

110. Keatings, V.M.; Collins, P.D.; Scott, D.M.; Barnes, P.J. Differences in interleukin-8 and tumor necrosis factor-alpha in induced sputum from patients with chronic obstructive pulmonary disease or asthma. Am. J. Respir. Crit. Care Med. 1996, 153, 530-534. [CrossRef]

111. Beckett, E.L.; Stevens, R.L.; Jarnicki, A.G.; Kim, R.Y.; Hanish, I.; Hansbro, N.G.; Deane, A.; Keely, S.; Horvat, J.C.; Yang, M.; et al. A new short-term mouse model of chronic obstructive pulmonary disease identifies a role for mast cell tryptase in pathogenesis. J. Allergy Clin. Immunol. 2013, 131, 752-762. [CrossRef]

112. Thatcher, T.H.; Maggirwar, S.B.; Baglole, C.J.; Lakatos, H.F.; Gasiewicz, T.A.; Phipps, R.P.; Sime, P.J. Aryl hydrocarbon receptor-deficient mice develop heightened inflammatory responses to cigarette smoke and endotoxin associated with rapid loss of the nuclear factor-kappaB component RelB. Am. J. Pathol. 2007, 170, 855-864. [CrossRef] [PubMed]

113. Vogel, C.F.; Matsumura, F. A new cross-talk between the aryl hydrocarbon receptor and RelB, a member of the NF-kappaB family. Biochem. Pharmacol. 2009, 77, 734-745. [CrossRef] [PubMed]

114. Iu, M.; Zago, M.; Rico de Souza, A.; Bouttier, M.; Pareek, S.; White, J.H.; Hamid, Q.; Eidelman, D.H.; Baglole, C.J. RelB attenuates cigarette smoke extract-induced apoptosis in association with transcriptional regulation of the aryl hydrocarbon receptor. Free Radic. Biol. Med. 2017, 108, 19-31. [CrossRef] [PubMed]

115. Sheridan, J.A.; Zago, M.; Nair, P.; Li, P.Z.; Bourbeau, J.; Tan, W.C.; Hamid, Q.; Eidelman, D.H.; Benedetti, A.L.; Baglole, C.J. Decreased expression of the NF-kappaB family member RelB in lung fibroblasts from Smokers with and without COPD potentiates cigarette smoke-induced COX-2 expression. Respir. Res. 2015, 16, 54. [CrossRef] [PubMed]

116. Martel-Pelletier, J.; Lajeunesse, D.; Reboul, P.; Pelletier, J.P. Therapeutic role of dual inhibitors of 5-LOX and COX, selective and non-selective non-steroidal anti-inflammatory drugs. Ann. Rheum. Dis. 2003, 62, 501-509. [CrossRef] [PubMed]

117. Roh, G.S.; Yi, C.O.; Cho, Y.J.; Jeon, B.T.; Nizamudtinova, I.T.; Kim, H.J.; Kim, J.H.; Oh, Y.M.; Huh, J.W.; Lee, J.H.; et al. Anti-inflammatory effects of celecoxib in rat lungs with smoke-induced emphysema. Am. J. Physiol. Lung Cell. Mol. Physiol. 2010, 299, L184-L191. [CrossRef]

118. Seidel, S.D.; Winters, G.M.; Rogers, W.J.; Ziccardi, M.H.; Li, V.; Keser, B.; Denison, M.S. Activation of the Ah receptor signaling pathway by prostaglandins. J. Biochem. Mol. Toxicol. 2001, 15, 187-196. [CrossRef]

119. Sharafkhaneh, A.; Hanania, N.A.; Kim, V. Pathogenesis of emphysema: From the bench to the bedside. Proc. Am. Thorac. Soc. 2008, 5, 475-477. [CrossRef]

120. Boukhenouna, S.; Wilson, M.A.; Bahmed, K.; Kosmider, B. Reactive Oxygen Species in Chronic Obstructive Pulmonary Disease. Oxid. Med. Cell. Longev. 2018, 2018, 5730395. [CrossRef]

121. Church, D.F.; Pryor, W.A. Free-radical chemistry of cigarette smoke and its toxicological implications. Environ. Health Perspect. 1985, 64, 111-126. [CrossRef]

122. Hanta, I.; Kocabas, A.; Canacankatan, N.; Kuleci, S.; Seydaoglu, G. Oxidant-antioxidant balance in patients with COPD. Lung 2006, 184, 51-55. [CrossRef] [PubMed]

123. Tavilani, H.; Nadi, E.; Karimi, J.; Goodarzi, M.T. Oxidative stress in COPD patients, smokers, and non-smokers. Respir. Care 2012, 57, 2090-2094. [CrossRef] [PubMed]

124. Cristovao, C.; Cristovao, L.; Nogueira, F.; Bicho, M. Evaluation of the oxidant and antioxidant balance in the pathogenesis of chronic obstructive pulmonary disease. Rev. Port Pneumol. 2013, 19, 70-75. [CrossRef] 
125. Elmasry, S.A.-A.M.; Ghoneim, A.; Nasr, M.; AboZaid, M. Role of oxidant-antioxidant imbalance in the pathogenesis of chronic obstructive pulmonary disease. Egypt. J. Chest Dis. Tuberc. 2015, 64, 813-820. [CrossRef]

126. Aoshiba, K.; Yokohori, N.; Nagai, A. Alveolar wall apoptosis causes lung destruction and emphysematous changes. Am. J. Respir. Cell Mol. Biol. 2003, 28, 555-562. [CrossRef] [PubMed]

127. Morissette, M.C.; Parent, J.; Milot, J. Alveolar epithelial and endothelial cell apoptosis in emphysema: What we know and what we need to know. Int. J. Chron. Obstr. Pulm. Dis. 2009, 4, 19-31.

128. Plantier, L.; Boczkowski, J.; Crestani, B. Defect of alveolar regeneration in pulmonary emphysema: Role of lung fibroblasts. Int. J. Chron. Obstr. Pulm. Dis. 2007, 2, 463-469.

129. Kosmider, B.; Messier, E.M.; Chu, H.W.; Mason, R.J. Human alveolar epithelial cell injury induced by cigarette smoke. PLoS ONE 2011, 6, e26059. [CrossRef]

130. Baglole, C.J.; Bushinsky, S.M.; Garcia, T.M.; Kode, A.; Rahman, I.; Sime, P.J.; Phipps, R.P. Differential induction of apoptosis by cigarette smoke extract in primary human lung fibroblast strains: Implications for emphysema. Am. J. Physiol. Lung Cell. Mol. Physiol. 2006, 291, L19-L29. [CrossRef]

131. Hu, W.; Xie, J.; Zhao, J.; Xu, Y.; Yang, S.; Ni, W. Involvement of Bcl-2 family in apoptosis and signal pathways induced by cigarette smoke extract in the human airway smooth muscle cells. DNA Cell Biol. 2009, 28, 13-22. [CrossRef]

132. Zhang, L.; Guo, X.; Xie, W.; Li, Y.; Ma, M.; Yuan, T.; Luo, B. Resveratrol exerts an anti-apoptotic effect on human bronchial epithelial cells undergoing cigarette smoke exposure. Mol. Med. Rep. 2015, 11, 1752-1758. [CrossRef] [PubMed]

133. Nana-Sinkam, S.P.; Lee, J.D.; Sotto-Santiago, S.; Stearman, R.S.; Keith, R.L.; Choudhury, Q.; Cool, C.; Parr, J.; Moore, M.D.; Bull, T.M.; et al. Prostacyclin prevents pulmonary endothelial cell apoptosis induced by cigarette smoke. Am. J. Respir. Crit. Care Med. 2007, 175, 676-685. [CrossRef] [PubMed]

134. Demedts, I.K.; Demoor, T.; Bracke, K.R.; Joos, G.F.; Brusselle, G.G. Role of apoptosis in the pathogenesis of COPD and pulmonary emphysema. Respir. Res. 2006, 7, 53. [CrossRef] [PubMed]

135. Hecht, E.; Zago, M.; Sarill, M.; Rico de Souza, A.; Gomez, A.; Matthews, J.; Hamid, Q.; Eidelman, D.H.; Baglole, C.J. Aryl hydrocarbon receptor-dependent regulation of miR-196a expression controls lung fibroblast apoptosis but not proliferation. Toxicol. Appl. Pharmacol. 2014, 280, 511-525. [CrossRef]

136. Shivanna, B.; Maity, S.; Zhang, S.; Patel, A.; Jiang, W.; Wang, L.; Welty, S.E.; Belmont, J.; Coarfa, C.; Moorthy, B. Gene Expression Profiling Identifies Cell Proliferation and Inflammation as the Predominant Pathways Regulated by Aryl Hydrocarbon Receptor in Primary Human Fetal Lung Cells Exposed to Hyperoxia. Toxicol. Sci. 2016, 152, 155-168. [CrossRef] [PubMed]

137. Holz, O.; Zuhlke, I.; Jaksztat, E.; Muller, K.C.; Welker, L.; Nakashima, M.; Diemel, K.D.; Branscheid, D.; Magnussen, H.; Jorres, R.A. Lung fibroblasts from patients with emphysema show a reduced proliferation rate in culture. Eur. Respir. J. 2004, 24, 575-579. [CrossRef] [PubMed]

138. Bartling, B.; Hofmann, H.S. Reduced proliferation capacity of lung cells in chronic obstructive pulmonary disease. Z. Gerontol. Geriatr. 2018. [CrossRef]

139. Tsuji, T.; Aoshiba, K.; Nagai, A. Alveolar cell senescence in patients with pulmonary emphysema. Am. J. Respir. Crit. Care Med. 2006, 174, 886-893. [CrossRef]

140. Alexander, D.L.; Ganem, L.G.; Fernandez-Salguero, P.; Gonzalez, F.; Jefcoate, C.R. Aryl-hydrocarbon receptor is an inhibitory regulator of lipid synthesis and of commitment to adipogenesis. J. Cell Sci. 1998, 111 Pt 22, 3311-3322.

141. Miravitlles, M.; Ferrer, M.; Pont, A.; Zalacain, R.; Alvarez-Sala, J.L.; Masa, F.; Verea, H.; Murio, C.; Ros, F.; Vidal, R.; et al. Effect of exacerbations on quality of life in patients with chronic obstructive pulmonary disease: A 2 year follow up study. Thorax 2004, 59, 387-395. [CrossRef]

142. Sapey, E.; Stockley, R.A. COPD exacerbations. 2: Aetiology. Thorax 2006, 61, 250-258. [CrossRef] [PubMed]

143. Albert, R.K.; Connett, J.; Bailey, W.C.; Casaburi, R.; Cooper, J.A., Jr.; Criner, G.J.; Curtis, J.L.; Dransfield, M.T.; Han, M.K.; Lazarus, S.C.; et al. Azithromycin for prevention of exacerbations of COPD. N. Engl. J. Med. 2011, 365, 689-698. [CrossRef] [PubMed]

144. Sethi, S. Infection as a comorbidity of COPD. Eur. Respir. J. 2010, 35, 1209-1215. [CrossRef] [PubMed]

145. Vorderstrasse, B.A.; Lawrence, B.P. Protection against lethal challenge with Streptococcus pneumoniae is conferred by aryl hydrocarbon receptor activation but is not associated with an enhanced inflammatory response. Infect. Immun. 2006, 74, 5679-5686. [CrossRef] 
146. Roussel, L.; LaFayette, S.; Nguyen, D.; Baglole, C.J.; Rousseau, S. Differential Contribution of the Aryl-Hydrocarbon Receptor and Toll-Like Receptor Pathways to IL-8 Expression in Normal and Cystic Fibrosis Airway Epithelial Cells Exposed to Pseudomonas aeruginosa. Front. Cell Dev. Biol. 2016, 4, 148. [CrossRef] [PubMed]

147. Kolluri, S.K.; Weiss, C.; Koff, A.; Gottlicher, M. p27(Kip1) induction and inhibition of proliferation by the intracellular Ah receptor in developing thymus and hepatoma cells. Genes Dev. 1999, 13, 1742-1753. [CrossRef]

148. Puga, A.; Barnes, S.J.; Dalton, T.P.; Chang, C.; Knudsen, E.S.; Maier, M.A. Aromatic hydrocarbon receptor interaction with the retinoblastoma protein potentiates repression of E2F-dependent transcription and cell cycle arrest. J. Biol. Chem. 2000, 275, 2943-2950. [CrossRef] [PubMed]

149. Pang, P.H.; Lin, Y.H.; Lee, Y.H.; Hou, H.H.; Hsu, S.P.; Juan, S.H. Molecular mechanisms of p21 and p27 induction by 3-methylcholanthrene, an aryl-hydrocarbon receptor agonist, involved in antiproliferation of human umbilical vascular endothelial cells. J. Cell. Physiol. 2008, 215, 161-171. [CrossRef]

150. Kalmes, M.; Hennen, J.; Clemens, J.; Blomeke, B. Impact of aryl hydrocarbon receptor (AhR) knockdown on cell cycle progression in human HaCaT keratinocytes. Biol. Chem. 2011, 392, 643-651. [CrossRef]

151. Yamaguchi, K.; Matulka, R.A.; Shneider, A.M.; Toselli, P.; Trombino, A.F.; Yang, S.; Hafer, L.J.; Mann, K.K.; Tao, X.J.; Tilly, J.L.; et al. Induction of PreB cell apoptosis by 7,12-dimethylbenz[a]anthracene in long-term primary murine bone marrow cultures. Toxicol. Appl. Pharmacol. 1997, 147, 190-203. [CrossRef]

152. Wu, R.; Zhang, L.; Hoagland, M.S.; Swanson, H.I. Lack of the aryl hydrocarbon receptor leads to impaired activation of AKT/protein kinase B and enhanced sensitivity to apoptosis induced via the intrinsic pathway. J. Pharmacol. Exp. Ther. 2007, 320, 448-457. [CrossRef] [PubMed]

153. Marlowe, J.L.; Fan, Y.; Chang, X.; Peng, L.; Knudsen, E.S.; Xia, Y.; Puga, A. The aryl hydrocarbon receptor binds to E2F1 and inhibits E2F1-induced apoptosis. Mol. Biol. Cell 2008, 19, 3263-3271. [CrossRef] [PubMed]

154. Sanchez-Martin, F.J.; Fernandez-Salguero, P.M.; Merino, J.M. 2,3,7,8-Tetrachlorodibenzo-p-dioxin induces apoptosis in neural growth factor (NGF)-differentiated pheochromocytoma PC12 cells. Neurotoxicology 2010, 31, 267-276. [CrossRef] [PubMed]

155. Prokipcak, R.D.; Okey, A.B. Downregulation of the Ah receptor in mouse hepatoma cells treated in culture with 2,3,7,8-tetrachlorodibenzo-p-dioxin. Can. J. Physiol. Pharmacol. 1991, 69, 1204-1210. [CrossRef] [PubMed]

156. Pollenz, R.S. Specific blockage of ligand-induced degradation of the Ah receptor by proteasome but not calpain inhibitors in cell culture lines from different species. Biochem. Pharmacol. 2007, 74, 131-143. [CrossRef] [PubMed]

157. Ehrlich, A.K.; Kerkvliet, N.I. Is chronic AhR activation by rapidly metabolized ligands safe for the treatment of immune-mediated diseases? Curr. Opin. Toxicol. 2017, 2, 72-78. [CrossRef] [PubMed] 